\title{
First Record of Mysaromima liquescens Meyric (Lepidoptera: Elaschistidae) Damaging Paricá (Schizolobium parahyba var. amazonicum)
}

\author{
RM PITTA ${ }^{1}$, FJ WRUCK ${ }^{2}$ \\ ${ }^{1}$ Embrapa Agrossilvipastoril, Sinop, MT, Brasil \\ ${ }^{2}$ Embrapa Arroz e Feijão, Santo Antônio de Goiás, GO, Brasil
}

\section{Keywords}

Amazonian tree, Borer, Insect pest, Plantinsect interaction

\section{Correspondence}

RM Pitta, Embrapa Agrossilvipastoril, 78556-970 Sinop, MT, Brasil; rafael.pitta@embrapa.br

Edited by Fernando L Cônsoli - ESALO/USP

Received 3 July 2013 and accepted 10 February 2014

(C) Sociedade Entomológica do Brasil 2014

\begin{abstract}
We report Paricá as the first host recorded for Mysaromima liquescens Meyrick, and the damaging potential of $M$. liquescens larvae as borers in Nova Canaã do Norte, state of Mato Grosso, Brazil.
\end{abstract}

Paricá (Schizolobium parahyba var. amazonicum) is an Amazonian fast-growing tree widely planted in reforestation areas in the Amazon biome due to its adaptability to different environmental conditions and satisfactory economic value (Rosa 2006). As a consequence of an intensification of its cultivation, new Paricáinsect interactions have been reported, especially for pests species, such as for Quesada gigas Olivier (Zanuncio et al 2004), Solenopsis saevissima F. Smith (Lunz et al 2009) and Pantophthalmus kerteszianus Enderlein and Pantophthalmus chuni Enderlein (Lunz et al 2010).

We now report on the association of Mysaromima liquescens Meyrick with Paricá and on its potential as a pest. $M$. liquescens larvae were found causing severe damage to Paricá trees cultivated in an agrosilvopastoral system $\left(10^{\circ} 24^{\prime} 06^{\prime \prime S}, 55^{\circ} 43^{\prime} 35^{\prime \prime} \mathrm{W}\right)$ in Nova Canaã do Norte, state of Mato Grosso, Brazil, in July 2012. The infestation reached an average of $12-14$ larvae $(2.5-\mathrm{cm}$ in length) per plant. Larvae built 3-cm deep galleries from the bark towards the heartwood tree. It was possible to see a tube composed of caterpillar's excrements and wood exudates frequently located either in scars at the insertion of petioles or in wounds (Fig 1a) provoked by the cattle gnawing the bark of the trees.

Samples of the trunks were cut and kept in the laboratory until adult emergence. The adult specimens obtained were 12-mm long, with a 40-mm wingspan, forewings rather broad with two black oval spot surrounded above and posterior with a greenish color mixed with gray; hind wings were pale colored (Fig 1b).

In its original description, specimens of $M$. liquescens were collected in Colombia (Meyrick 1926), but no hosts were reported. Therefore, Paricá is the first record of a host to this species.

Due to the severity of the attack, research into the population dynamic of $M$. liquescens, its biology, and behavior are needed in order to support further studies for the management of this species in Paricá. 
Fig 1 a Tube composed of caterpillar's excrements and wood exudates. b Adult specimen of Mysaromima liquescens.
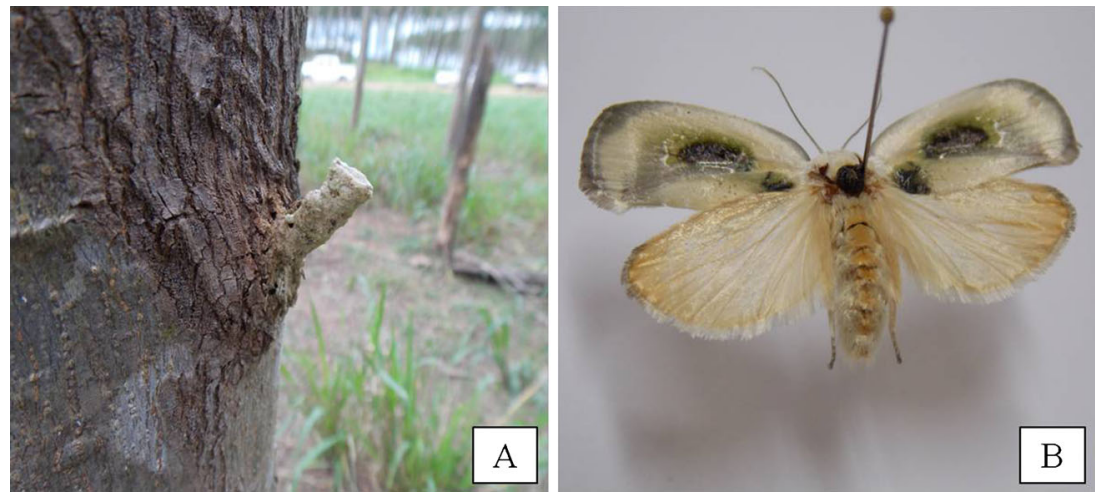

Acknowledgments Authors thank Dr. Vitor O. Becker for the identification of Mysaromima liquescens.

\section{References}

dos Rosa LS (2006) Ecologia e silvicultura do paricá (Schizolobium amazonicum Huber ex Ducke) na Amazônia brasileira. Rev Ciênc Agrár 45:135-174

Lunz AM, Harada AY, Aguiar TS, Cardoso AS (2009) Danos de Solenopsis saevissima F Smith (Hymenoptera: Formicidae) em
Paricá, Schizolobium amazonicum. Neotrop Entomol 38:285288

Lunz AM, Batista TFC, Rosário VSV, Monteiro OM, Mahon AC (2010) Ocorrência de Pantophthalmus kerteszianus e $P$. chuni (Diptera: Pantophthalmidae) em paricá, no Estado do Pará. Pesq Florest Bras 30:71-74

Meyrick E (1926) Exotic Microlepidoptera, http://archive.org/stream/ exoticmicrolepido3meyr\#page/n5/mode/2up. Accessed: 16 Apr 2013 Zanuncio JC, Pereira FF, Zanuncio TV, Martinelli NM, Pinon TBM, Guimarães EM (2004) Ocurrence of Quesada gigas on Schizolobium amazonicum trees in Maranhão and Pará States, Brazil. Pesq Agropec Bras 39:943-945 